\title{
Analysis of hospital flow management: the 3 R's approach
}

\author{
Bruna Dones Gayer ${ }^{\mathrm{a}}$, Érico Marcon ${ }^{\mathrm{a} *}$ (D), Wagner Pietrobelli Bueno ${ }^{\mathrm{a}}$ (D), Priscila Wachs ${ }^{\mathrm{a}}$ (iD, \\ Tarcisio Abreu Saurin ${ }^{\mathrm{a}}$ (D), Paulo Ghinato ${ }^{\mathrm{b}}$ \\ ${ }^{a}$ Universidade Federal do Rio Grande do Sul, Porto Alegre, RS, Brasil

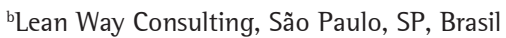 \\ *erico.marcon@hotmail.com
}

\begin{abstract}
Paper aims: This article aims to study the logistics problems in Brazilian hospitals through Lean methods, approaching different aspects of logistics and the procedures adopted in health institutions such as receiving, storage and transporting.

Originality: The rising of hospitals' costs is importantly impacted by hospital logistics. They are caused by aspects such as unstandardized processes and inadequate layout and equipment in critical stages of logistic operations. However, these problems are rarely addressed in literature.
\end{abstract}

Research method: We developed, through Design Science Research and lean tools, a model based on route, rhythm and routine (3 R's) that enables the identification of logistics problems.

Main findings: Hospitals present complex logistic operations. The application of the model developed identified improvement opportunities due to unnecessary activities, lack of space and infrastructure, and lack of standardized procedures. These findings enable improvements in operations and a better comprehension of the factors that impact the processes of internal logistics.

Implications for theory and practice: The model provides a comprehensive view of the logistical process, its stages and aspects of improvement. Therefore, hospital managers can better identify and address logistical problems directly at non-value adding activities. Adaptations may be required due to the healthcare environment specificities.

Keywords

Route. Rhythm. Routine. Hospital logistic flow. Lean healthcare.

How to cite this article: Gayer, B. D., Marcon, É., Bueno, W. P., Wachs, P., Saurin, T. A., \& Ghinato, P. (2020). Analysis of hospital flow management: the 3 R's approach. Production, 30, e20200033. https://doi.org/10.1590/0103-6513.20200033

Received: Apr. 1, 2020; Accepted: July 13, 2020.

\section{Introduction}

Companies have been investing toward the lean journey in several manners. One of the areas of progress has been in logistics, commonly called Lean Logistics (Alves \& Santos, 2013). This logistics approach based upon lean principles comprises a set of tools, in order to manage systems effectively for storage control, material transportation, work-in-process material and finished goods (Rivard-Royer et al., 2002; Hopp \& Spearman, 2011). The benefits, according to Zylstra (2012) are the maximization of the quality of services and the products to the consumers, and moreover, stocks and non-value adding activities reduction.

Given the growing costs of healthcare in general, the materials management can contribute to reducing these costs while attending patients efficiently (Brandao de Souza, 2009; Volland et al., 2017). Several studies have pointed out the benefits of using lean production in healthcare, known as Lean Healthcare, such as Graban (2011), Brandao de Souza (2009) and Mazzocato et al. (2010). Therefore, practices of internal logistics allied with lean principles can bring benefits to materials management in hospitals either by optimizing the flow of 
materials, information or people (Liker \& Karlin, 2018). According to Rivard-Royer et al. (2002), healthcare institutions that applied lean tools reached considerable savings and reduced their inventory by nearly $80 \%$. Additionally, the problem becomes even more relevant as high expenditures in logistics are responsible for more than $30 \%$ of the costs inside a hospital according to Volland et al. (2017).

Given the complexity of the internal logistics of hospitals, mainly caused by the diversity of supplies and distribution channels by which they flow, the present study discusses a Logistical Supply Unit of a large university hospital located in Southern Brazil. The objectives of the study are: (i) to propose a model to analyze flow management, considering aspects of route, rhythm and routine; (ii) to analyze and propose improvements for managing the flow of supplies (medicine, serum and medical material) in the pharmaceutical supply unit of the hospital. The route, rhythm and routine subordinated to the flow provide support for value stream and guarantee an improvement in the management of the logistics processes, that should always be focused in offering stability and capacity (Harris et al., 2003; Ghinato, 2016). In this way, the proposed model presents the combined application of these three essential components of standardized movement (route, rhythm, and routine), applied in the medicines flow of a hospital.

It is worth noting that in-depth studies concerning transportation management (flow) of medicines are scarce. Studies in lean healthcare, on the other hand, direct efforts to the patient flow in hospitals, just like the studies carried out by Bushell \& Shelest (2002), Aherne \& Whelton (2010), Hall et al. (2013) and Kc \& Terwiesch (2017). Some studies concerning specifically lean logistics should be mentioned: Heinbuch (1995), proposing a reduction of hospital material stocks using pull production tools; Jimmerson et al. (2005), who proposed improvements for the problem of the disappearance of stocks of medicines in hospital internal pharmacies; Regattieri et al. (2018) with a two-step model for logistics improvement in hospitals. However, there are few empirical studies addressing the flow of material in hospitals, such as we propose in this study.

Structurally, this article is composed of the following sections: section 2 brings the theoretical basis for the research, the next section presents the method adopted for the model development. Section 4 presents the results derived from the study and the model developed and the section 5 presents a discussion about it. Finally, section 6 addresses the conclusions of the study, suggestions for future research and limitations of the present article.

\section{Literature review}

\subsection{Lean logistics in healthcare}

Healthcare organizations have the challenge of supplying products of high quality in environments of limited resources. Therefore, they can benefit from the elimination of wastes proposed by lean approaches (Khlie et al., 2016). From the perspective of Lean Logistics, the transportation of materials and products up to the patient (final client) is an obscure and often neglected activity, but of essential importance for the operation of all the supplies activities of a hospital unit (Kriegel et al., 2013; Volland et al., 2017).

From the perspective of Lean Logistics in healthcare, it is first necessary to understand what adds value to the patient. This is a great challenge since transport itself is an activity considered to be a waste, according to Ohno (1988). To improve the internal logistics through lean approaches, it is critical to study the flow of information, material and client/patient relationship, in order to identify the activities that add and that not add value (Rother \& Shook, 2003, Regattieri et al., 2018; Feibert et al., 2019). Aligned with the seven wastes identified by Ohno (1988), Sutherland \& Bennett (2007) describe wastes from the perspective of logistics, as shown in Table 1 below.

Table 1 . Wastes from the perspective of lean logistics.

\begin{tabular}{|c|c|c|}
\hline & 7 wastes in lean logistics & Description of each waste \\
\hline 1 & Overproduction & It is the delivery of materials before they are needed. \\
\hline 2 & Delay/Waiting & $\begin{array}{l}\text { It is any delay between the end of one activity and the start of the next activity (e.g. the time between the } \\
\text { arrival of a truck for a pick-up and the loading of the trailer). }\end{array}$ \\
\hline 3 & Transportation/Conveyance & Unnecessary transport that results in added cost. \\
\hline 4 & Motion & Unnecessary movement of people (e.g. walking, reaching and stretching). \\
\hline 5 & Inventory & $\begin{array}{l}\text { Any logistics activity that results in more inventory being positioned than needed or in a location other } \\
\text { than where needed. }\end{array}$ \\
\hline 6 & Space & $\begin{array}{l}\text { Use of space that is less than optimal. Examples include less than full/optimal trailer loads, cartons that are } \\
\text { not filled to their full capacity, inefficient use of warehouse space, and even loads over the capacity. }\end{array}$ \\
\hline 7 & Errors & $\begin{array}{l}\text { Any activity that causes rework, unnecessary adjustments or returns (e.g. billing errors, inventory } \\
\text { discrepancies, and defective/wrong product). }\end{array}$ \\
\hline
\end{tabular}


The same wastes identified by Ohno (1988) and Sutherland \& Bennett (2007) are present in the hospital environment, as exemplified by Khlie et al. (2016). Thus, the application of lean principles in healthcare logistics is beneficial to the process due to several reasons: health institutions are organized into departments and, by applying the lean mentality, specifically the continuous value flow, the mentality focused on departments will be substituted, allowing changes to occur (Poksinska et al., 2017). Still, according to the authors, much of the work performed within health organizations do not add value to the process directly, as is the case of receiving and transporting hospital materials. Finally, logistics problems are increased since staff entrusted with logistics activities inside hospitals do not have logistics background (Volland et al., 2017).

From a Lean Logistics operational point of view, the application of flow analysis tools, such as Value Stream Map (VSM), Spaghetti Diagram and Swimlanes Chart have great importance to grasp the complexity of logistical problems in hospitals (Costa et al., 2017). VSM is a tool to identify sources of value and waste, and its most commonly used in the flow of materials (Rother \& Shook, 2003). Spaghetti Diagram is a quick and easy way to track distances of parts and people, and it is commonly used for analyzing the flow of people (e. g. employees, customers or routes of support resources) (Wilson, 2010). The Swimlanes Chart is an essential tool that documents the steps or activities of a process flow or workflow, and its focused mainly in demonstrating flows of communication (Rummler \& Brache, 2012).

\subsection{Route, Rhythm and Routine (3R's)}

A central aspect of the study of Lean Logistics is the standardization of the whole process of supplying the assembly lines, which is based on the minimization of materials transportation to its point of use. For this purpose, it is necessary to define the route and the supply cycle time, in order to ensure that there is no shortage of material to the assembly lines (Myerson, 2012).

From this concept of logistics and waste elimination, Ghinato (2016) states that the struggle against waste in logistics must be based on a fundamental concept: process management should be subordinate to flows that add value, ensuring stability and capacity to provide support for these flows. Flow management is established through the combined application of three essential components: standardized route, rhythm and a routine of movements, applicable to flows of all kinds (Ghinato, 2016).

Routes (first R) are defined, standardized and easily identifiable paths along which the entity (materials, information, employees, customers or support resources) should flow. These standardized routes seek to establish the shortest distances between processes and stages, the lower incidence of intersections and counterflows, promoting an optimized resource provision (impact on the layout, for example) and lower lead times (Ghinato, 2018). Visual management mechanisms are fundamental to the application of this first $R$, which, in a feedback loop, facilitates their management. Standardized routes allow the application of an essential rule of visual management (Ghinato, 2018): Me De Miru ("look and immediately understand"), avoiding possible occurrences of deviations.

The rhythm (the 2nd R) is the "pulse" or the "cadence" of the operation that guarantees the connection between processes from the "client-supplier" perspective. The flow goes from supplier to customer according to the consumption needs of the customer. In this way, the supplier process and all supporting resources will be focused on ensuring a continuous flow of supply to the customer process (Ghinato, 2018). In the lean operations management logic, the rhythm is expressed by the takt-time. Takt-time is expressed by the equation "total time available in the period/demand in the period", which is the "elapsed time between two consecutive flow units" (product, in this case, the material flow), dictated by demand (Marchwinski \& Shook, 2003).

Routines of movement (the third R) are the sequences of activities of manipulation of the object in the flow (material, information, people, etc.), executed cyclically, in order to guarantee the flow through the routes, in a specific and defined rhythm. An analogy that can best picture the standardized routine movement in a lean environment is the movement of the buses by itineraries, stopping at defined points, at known and standardized times, in order to leave and collect passengers. Standardized movement routines are performed by flow agents (named mizusumashi) commonly called feeders or movers (Ghinato, 2018).

Even though some studies have addressed the improvements necessary for hospital logistics through lean concepts (Regattieri et al., 2018; Gao \& Gurd, 2019; Papalexi et al., 2016), the results usually provide clarity on specific changes and practices, without standard procedures or wide process improvement strategies (Maijala et al., 2018). Examples of this are the studies that present the implementation of lean tools such as the use of Gemba, root cause analysis, and metric tools for measuring and monitoring improvement (Goodridge et al., 2015; Maijala et al., 2018). In this sense, Gao \& Gurd (2019) state that 5S, Value Stream Mapping, Fishbone diagram, and Six Sigma are among the most used tools applied in hospitals. Alternatively, Papalexi et al., (2016) 
propose the use of Kanban for a pharmaceutical supply chain to significantly reduce inventory levels and costs, while reducing waste.

Since the proposition of specific lean countermeasures to reduce waste and seek a better flow are important for better productivity (Feibert et al., 2019), a systematic approach for the evaluation of healthcare logistic problems and its improvements is expected to allow better results, as hospitals are pursuing lean as a systemic path, with an increased focus on the strategic side (Gao \& Gurd, 2019). An example is the two-phase procedure for materials management improvement in hospitals proposed by Regattieri et al. (2018) that is firstly based on an analysis of the initial situation and introducing basic methods (physical and information flow, supply times, training on material's logistics) and then with the introduction of modern solutions (such as RFID).

Therefore, the relevance of proposing a structured approach such as the 3 R's relies on the importance and its capability of cost reduction in healthcare, which is the second largest cost block in hospitals (Volland et al., 2017). Thus, the 3 R's enable a broader view and systematic process for identifying and solving logistics problems, instead of specific lean tools that can be difficult to be adapted for the healthcare context, especially in the logistics area, where sophisticated concepts may be rather difficult to be implemented (Volland et al., 2017).

\section{Method}

\subsection{Methodological approach}

The Design Science Research (DSR) was the methodological approach chosen to develop this study, due to its characteristics as developing problem solution knowledge through the creation of new artifacts or improving existing artifacts (Van Aken, 2004; Holmström et al., 2009). Artifacts in DSR are understood as constructs, models, methods, and instantiations (March \& Smith, 1995). The DSR prescriptive characteristic allows the researcher to, besides the understanding of the problem, focus on improving practical problems (Holmström et al., 2009).

Vaishnavi \& Kuechler (2007) present five phases for DSR: (1) identification and understanding of the problem; (2) suggestion and discussions of possible solutions; (3) development of chosen suggestions; (4) evaluation and analysis of planned and unplanned results, which allows rethinking the previous phases; and (5) conclusion. The authors emphasize that the phases are iterative, being modified and complemented through the research development.

The case study was conducted in a Brazilian university hospital, which has over 6,000 employees and around 1,700 daily appointments including a range of services, such as hospitalizations, appointments, exams, surgical procedures, deliveries, transplant procedures, low complexity procedures, and therapeutic sessions. It is worth noting that this study is part of a larger research project, related to quality and safety in health care institutions. The larger research project was approved by the hospital's ethical review board. Additionally, previous and complementary studies of the serum flow can be found at Gayer et al. $(2018,2019)$.

\subsection{The proposed model to analyze the logistic flow, considering Route, Rhythm, and Routine}

The proposed model was developed throughout the study, which is characteristic of studies that use DSR as a methodological approach (March \& Smith, 1995). The model is composed of five large steps, as shown in Figure 1 and detailed in Table 2.

Table 2. Proposed model steps description.

\begin{tabular}{|c|c|c|}
\hline Steps & Expected outputs & $\begin{array}{l}\text { Strategies to operationalize the proposed } \\
\text { model }\end{array}$ \\
\hline $\begin{array}{l}\text { Establishing common } \\
\text { ground about the } \\
\text { problem studied }\end{array}$ & $\begin{array}{l}\text { Initial phase, important for setting a conceptual alignment between } \\
\text { the problem studied and expectations. } \\
\text { The expected output for this step is the definition of the study } \\
\text { problem and the characterization and overview of the context studied. }\end{array}$ & Meetings and observations of the context. \\
\hline $\begin{array}{l}\text { Analysis of the subject's } \\
\text { flow }\end{array}$ & $\begin{array}{l}\text { ldentification and description of the main events that the subject that } \\
\text { flows goes through over time and space. }\end{array}$ & Value Stream Mapping (VSM) \\
\hline $\begin{array}{l}\text { Definition of a flow for } \\
\text { in-depth analysis }\end{array}$ & $\begin{array}{l}\text { The definition of the flow for the in-depth analysis should take into } \\
\text { account the necessity of the context (a critical flow) or a simple flow } \\
\text { to develop the pilot study and improvement implementation. }\end{array}$ & $\begin{array}{l}\text { Meetings and results of the } \\
\text { VSM }\end{array}$ \\
\hline $\begin{array}{l}\text { Deep analysis of the } \\
\text { flow }\end{array}$ & $\begin{array}{l}\text { Highlight the variability of the work done in the gemba and analyze of } \\
\text { the logistics, considering the route, routine and rhythm. }\end{array}$ & $\begin{array}{l}\text { 3R's Checklist, supported by observations, } \\
\text { interviews and document analysis. }\end{array}$ \\
\hline $\begin{array}{l}\text { ldentification of } \\
\text { opportunities for } \\
\text { improvement }\end{array}$ & $\begin{array}{l}\text { The final step has as outcome a list of improvement opportunities, } \\
\text { related to the } 3 \text { Rs in logistics. }\end{array}$ & $\begin{array}{l}\text { Meetings to discuss the results of the previous } \\
\text { steps. }\end{array}$ \\
\hline
\end{tabular}




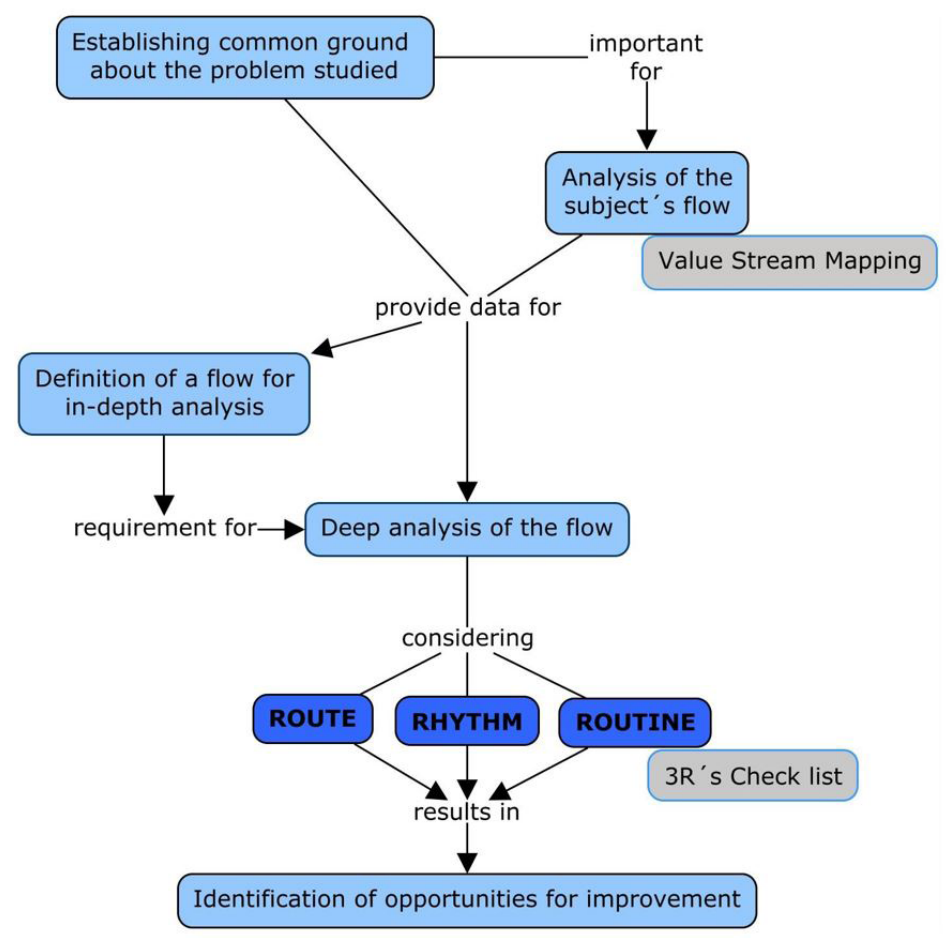

Figure 1. Proposed model for materials flow analysis, considering route, rhythm, and routine. Note: blue boxes - model steps; gray boxes - tools to support the analysis.

\subsection{Data collection and analysis}

In studies that use DSR as a methodological approach, meetings play a key role due to the interactive nature with the context studied. A total of seven meetings (total of 12.5 hours) were held. One of them had as objective to present the research team and discussing the project, the other two were internal meetings to discuss the stages "flow definition for in-depth analysis" and "in-depth analysis". And four meetings were related to the validation of the results, which was important to confirm and discuss the findings of the research: internal meeting for the validation of the value stream map, including two master students, two Ph.D. students and a professor ( 3 hours); after a meeting for the validation of the value stream map with the field study representatives ( 2 hours), including one leader of the sector of planning and purchase, three leaders of the logistics area and one leader of supply and distribution; two internal meetings ( 1.5 hours and 1 hour) for the validations of the logistics analysis, resulting in the definitions of the improving opportunities; the last meeting ( 2 hours) was held with the field study representatives and was done to validate the logistic analysis and improvement opportunities. The study lasted for approximately six months.

The data collection is composed of three instruments: observations, interviews, and document analysis. Table 3 presents the characteristics of the data collection. The data analysis was supported by VSM and the 3R's Checklist (developed by the authors for this study).

Table 3. Data collection.

\begin{tabular}{|c|c|c|}
\hline $\begin{array}{l}\text { Instruments for data } \\
\text { collection }\end{array}$ & Description & Data collection \\
\hline Observation & $\begin{array}{l}\text { Non-participant observations to deepen the } \\
\text { understanding of the context. }\end{array}$ & 70 hours in different shifts and times \\
\hline Interviews & $\begin{array}{l}\text { Semi-structured interviews to capture information } \\
\text { about the material flow and to identify improvement } \\
\text { opportunities. }\end{array}$ & $\begin{array}{l}6 \text { interviews (10-20 minutes each, a total of } 107 \text { minutes). } \\
\text { Participants that work in the logistics unit, covering the areas } \\
\text { of planning and procurement, separation of medications, } \\
\text { warehouse, restocking, inventory, and dispatch. }\end{array}$ \\
\hline Document analysis & $\begin{array}{l}\text { Aims to understand the prescribed work, so to } \\
\text { compare with the real work and to understand the } \\
\text { material flow. }\end{array}$ & $\begin{array}{l}\text { The analyzed documents were invoices, material requisitions } \\
\text { (internal request), operating system documents. }\end{array}$ \\
\hline
\end{tabular}




\subsubsection{Flow analysis}

Developed in the context of the Toyota Production System Xie \& Peng (2012) the VSM is a technique used to visualize a process as a whole and graphically represent the material and information flow to improve processes and identify sources of value and waste (Rother \& Shook, 2003). Therefore, the application of VSM is of great importance to grasp the complexity of logistical problems in hospitals, especially in the Brazilian context (Costa et al., 2017). Although it is possible to use other tools to analyze flows, such as Spaghetti Diagram to analyze the flow of people or Swimlanes Chart to analyze the information flow, the model in this study indicates the use of VSM, since it was designed to analyze the material flow.

Thus, in this study, the tool was developed through several visits to the hospital and interviews with employees that work in the areas of medication logistics. Its preliminary model was refined and evaluated with managers of the unit during meetings. Finally, we developed the final the VSM of the medicines of a hospital's Logistics Supply Unit, which is presented in Figure 2. The following steps of the method are based on the map developed to evaluate the processes that (i) do not add value, (ii) do not add value but are necessary, and (iii) add value Monden (1993), Rico \& Jagwani (2013), and thus, identify the priorities and the objectives of the framework proposed to solve logistical problems.

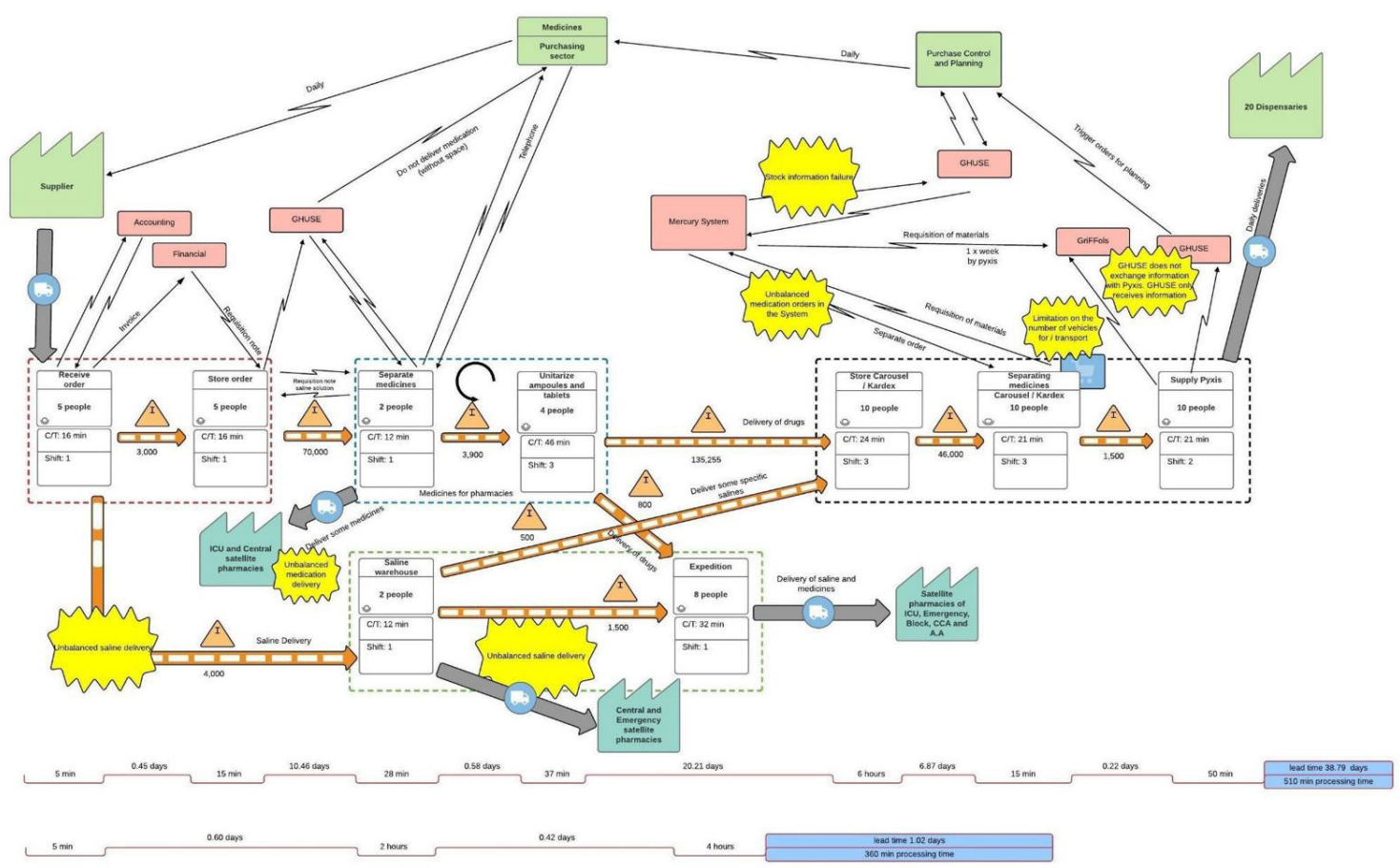

Figure 2. Value stream map of medicines (ampoules and tablets) and serum.

\subsubsection{Checklist: requirements for Route, Routine and Rhythm}

The Checklist (Table 4) presents the requirements to establish a standard route, rhythm, and routine, in the value flow of materials in a healthcare setting. The source of evidence is presented for each requirement, indicating which observation, interview and document analysis should be carried out, and each requirement is related to a lean principle. The development of the Checklist was based on Harris et al. (2003) and Ghinato (2018). The observations and interviews brought some insights to the development of the Checklist itself, such as the inclusion of the requirement "availability of elevators to transport the materials to the hospital units" and "the need to return the trolleys and boxes after delivering the materials in the units" (items 1.6 and 3.4 in the Checklist). This is evidence of the iterative process of the Design Science Research as a methodological approach. 


\begin{tabular}{|c|c|c|}
\hline & Requirements & Source of evidence \\
\hline \multirow[t]{7}{*}{ 1. Route } & $\begin{array}{l}1.1 \text { Locations for material storage are specific and } \\
\text { easy to access, optimizing the route. }\end{array}$ & To observe and/or interview employees of the material storage area. \\
\hline & $\begin{array}{l}\text { 1.2 Material is stored in the proper place at the first } \\
\text { time, avoiding further replacing. }\end{array}$ & To observe the route from the receiving sector to the stock of the material. \\
\hline & $\begin{array}{l}\text { 1.3 Adequate space for sorting, selecting and } \\
\text { checking batches of materials to be transported. }\end{array}$ & $\begin{array}{l}\text { To observe and/or interview employees that prepare the material for } \\
\text { transportation. }\end{array}$ \\
\hline & 1.4 Adequate space for people to move around. & To observe and/or interview employees from the logistics and storage units. \\
\hline & $\begin{array}{l}1.5 \text { Adequate space for transport devices (e.g. trolley, } \\
\text { skid steer loader, stretcher, and wheelchair). }\end{array}$ & $\begin{array}{l}\text { To observe and/or interview employees from the logistics and storage unit } \\
\text { and to identify aisles with adequate width. }\end{array}$ \\
\hline & $\begin{array}{l}\text { 1.6 Presence/availability of vertical and horizontal } \\
\text { displacement devices (e.g. service elevator and } \\
\text { pneumatic tubes). }\end{array}$ & $\begin{array}{l}\text { To observe displacement devices availability, and if it is shared with other } \\
\text { services. }\end{array}$ \\
\hline & 1.7 1dentification of a standard transportation route. & $\begin{array}{l}\text { To observe and/or interview and analyze documents about the routine of } \\
\text { the logistics and storage units. }\end{array}$ \\
\hline \multirow[t]{3}{*}{ 2. Rhythm } & $\begin{array}{l}2.1 \text { Supplier rhythm of delivery dictated by customer } \\
\text { demand. }\end{array}$ & $\begin{array}{l}\text { To interview employees from the planning area and/or review documents, } \\
\text { such as contracts with the supplier. }\end{array}$ \\
\hline & 2.2 Inventory size based on demand. & $\begin{array}{l}\text { To interview employees from the planning area and review documents, such } \\
\text { as inventory sizes records. }\end{array}$ \\
\hline & $\begin{array}{l}2.3 \text { Transportation rhythm dictated by the demand } \\
\text { of the client process. }\end{array}$ & $\begin{array}{l}\text { To interview employees from the logistics and distribution units and review } \\
\text { documents, such as material requisition records. }\end{array}$ \\
\hline \multirow[t]{4}{*}{ 3. Routine } & $\begin{array}{l}3.1 \text { Team mobilized at predetermined times for } \\
\text { receiving, preparing and transporting materials in } \\
\text { standardized frequency. }\end{array}$ & $\begin{array}{l}\text { To observe and/or interview and review documents about the routine in the } \\
\text { logistics and storage units. }\end{array}$ \\
\hline & 3.2 Materials standardly stored. & To observe if the stock has signalized and delimited stocking spaces. \\
\hline & $\begin{array}{l}\text { 3.3 Standardized sequence in batch preparation and } \\
\text { material distribution. }\end{array}$ & $\begin{array}{l}\text { To interview employees from the logistics and material distribution and } \\
\text { observe the existence of devices (cards, frames, empty boxes) that represent } \\
\text { the production sequence. }\end{array}$ \\
\hline & $\begin{array}{l}\text { 3.4 Standardized routine for returning empty boxes } \\
\text { and empty transport devices. }\end{array}$ & $\begin{array}{l}\text { To interview employees from the logistics and material distribution and to } \\
\text { observe if the routine of returning empty boxes and empty transport devices } \\
\text { is performed in a standardized frequency. }\end{array}$ \\
\hline
\end{tabular}

\subsection{Model validation}

The interactive feature of Design Science Research allows distinct moments of discussion about the results and model steps, which culminate in the consolidation of the proposed model. Besides those discussion and validation moments, a final moment was designated to discuss the model itself and the 3R's Checklist. The main artifact developed by this study is the logistics analysis model, but the 3 R's Checklist (part of the model) was also developed during the study and can be considered another artifact. The validation was done by two lean specialists, with four and twenty years of experience in lean respectively. The discussion allowed some refinements in the model, improving the theoretical and practical consistency of the study.

\section{Results}

\subsection{Overview of the context studied}

In the hospital studied, the researchers sought to understand the flow of materials, more precisely, the flow of serum, which according to the interviews and the Value Stream Mapping, is the most problematical logistics stream, and therefore it represents the strongest impact on operational effectiveness and reduction of lead time from order to delivery of the items. The unit in which such flow occurs is the Logistics Supply Unit (LSU), which supplies the whole hospital. Currently, LSU provides on average 6,680 medicines a day to 20 dispensaries. LSU has three sectors that comprise the logistics of medicines, namely (i) receipt, (ii) stock, and (iii) delivery. For the conduction of this study, the proposed framework for solving logistics problems (composed of Route, Rhythm, and Routine) was applied to the three logistics sectors of the hospital studied.

\subsection{Material flow analysis}

The development of the model had as its starting point the material flow analysis, delivered from the construction of the value stream map of the Logistics Supply Unit of the hospital, which was the application area of the study. In Figure 2 it is possible to observe 2 main material flows: the flow of medicines (ampoules 
and tablets) and the flow of serum, which includes all the serum used by the hospital, from the simplest ones, such as outpatients, to dialysis serums.

As shown in the value stream map, the dispatch of materials (operated by trolleys) follows through activities such as receipt, invoice checking, stocking, separation, and unitarization (for tablets). Requests made by internal pharmacies, emergency rooms, and surgical centers can arrive via Kardex (medicines organized in the electronic dispensaries) or via request of material (other medicines and serums).

\subsection{Scope definition for in-depth analysis}

From the Value Stream Mapping of all families of materials (Figure 2), the flow of serum shown in Figure 3 (Figure 2 magnified) was chosen as a pilot for in-depth analysis. According to Rother \& Harris (2001), in a scenario of improvements implementation, this comprehensive view in the mapping facilitates the visualization of how the flows interconnect and which is the best choice of flow to be addressed first. Smalley (2004) further state that aspects such as the nature of the problems identified and/or the intervention easiness should be taken into account in choosing the pilot flow to implement the improvements.

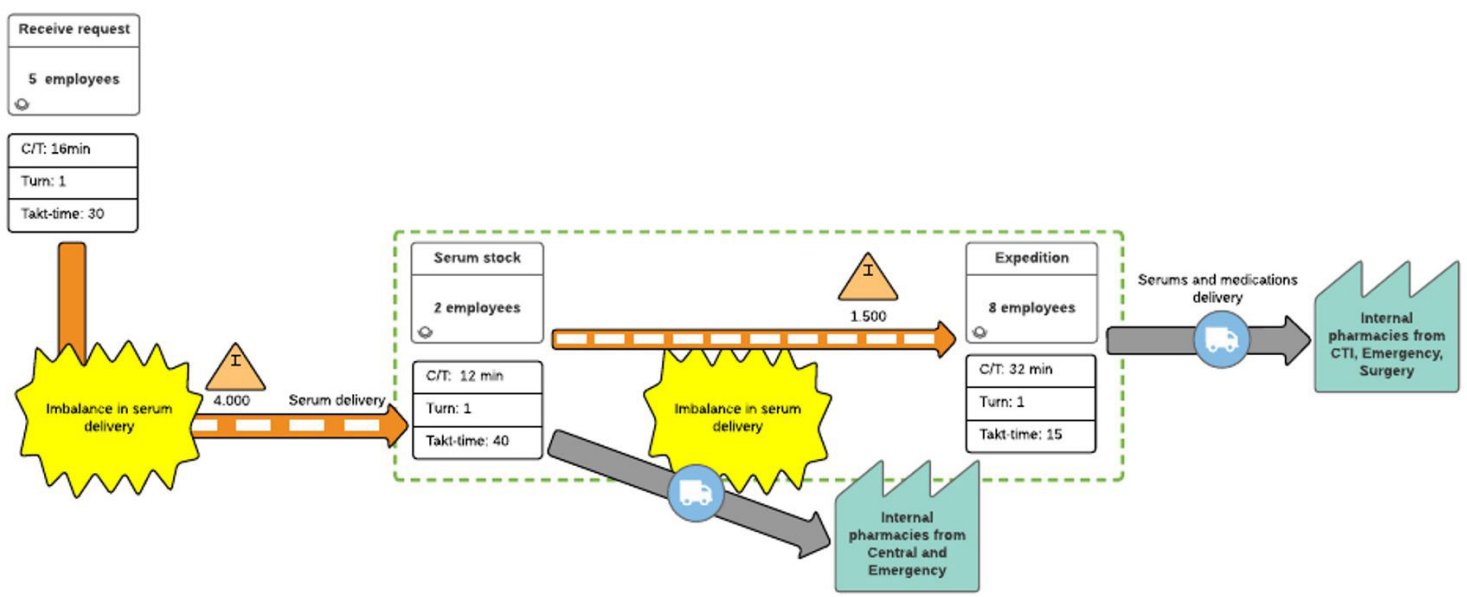

Figure 3. Value stream map of serums.

As the value stream map of the serums shows, the receipt process, where the invoice checking takes place, precedes the process of storing serum in the stock shelves. When a material is requested from an internal pharmacy, emergency room or surgical center, the activity of separation of the batch to be delivered to the delivery sector (material dispatch room) is triggered. In the dispatch process, the serums are checked and assembled in the same transport lot with other materials. A brief discussion about the serum flow and its improvement opportunities was presented by Gayer et al. (2018).

\subsection{Analysis of serum flow in the Logistics Supply Unit of the hospital}

To perform the analysis of the serum flow in the Logistics Supply Unit of the hospital, in addition to the analysis of the VSM already presented, we used the 3 R's checklist developed for this work (described in section 3.3.2). Based on the hospital supply chain model of Volland et al. (2017), the analysis of the 3 R's of serum flow was separated by the following areas: (a) receiving, characterized here by activities prior to storage, as request, reception, conference and billing; (b) stock, where the serums are received and where they are stocked centrally; (c) delivery, where the transportation of the materials is managed. Among the identified aspects in the case studied, stands out the lack of 3 main elements pointed out in the Checklist: lack of a standard route of transportation to the units, the pace of supplier operations not dictated by the rhythm (consumption) of the client operations resulting in high inventories and large lots of delivery and absence of a standardized routine for the return of the trolleys and the boxes. Table 5 below presents the complete analysis of 3R's applied to the serum flow. 
Table 5. Route, Rhythm and Routine analysis.

\begin{tabular}{|c|c|c|c|}
\hline & Route & Rhythm & Routine \\
\hline Receipt & $\begin{array}{l}\text { - Materials are not stored correctly at first; } \\
\text { - Congestion of boxes that arrive at the same } \\
\text { time from suppliers, hindering the movement of } \\
\text { employees; }\end{array}$ & $\begin{array}{l}\text { - It is not dictated by } \\
\text { the hospital's request } \\
\text { (customer), resulting in } \\
\text { large delivery batches; }\end{array}$ & $\begin{array}{l}\text { - There are no predetermined times for the } \\
\text { transportation of boxes from the receiving area to } \\
\text { the stock; } \\
\text { - There is no team mobilized at predetermined times } \\
\text { to transport boxes from receipt to stock; } \\
\text { - Unavailability of staff due to other tasks; }\end{array}$ \\
\hline Stock & $\begin{array}{l}\text { - Physical space for storage is insufficient; } \\
\text { - Inadequate space for the separation, selection, and } \\
\text { checking of materials to be transported; } \\
\text { - Transport of trolleys impaired by lack of space; } \\
\text { - Narrow aisles; } \\
\text { - There is no standard route of transportation until } \\
\text { the expedition; }\end{array}$ & $\begin{array}{l}\text { - Inventories last } \\
\text { approximately } 15 \text { days, } \\
\text { being unbalanced with } \\
\text { the rhythm printed by } \\
\text { the patients; }\end{array}$ & $\begin{array}{l}\text { - Material disposed in the stock in a non-standard } \\
\text { way (without visual management with fixed } \\
\text { demarcation for storage); } \\
\text { - Absence of a standardized sequence in the } \\
\text { preparation of serum to be dispatched; } \\
\text { - Time is wasted by removing the serum from the } \\
\text { cardboard boxes and placing them into green boxes; } \\
\text { - Unbalanced workload; }\end{array}$ \\
\hline Delivery & $\begin{array}{l}\text { - Lack of space for people movement and carriage, } \\
\text { due to the congestion of materials; } \\
\text { - Too much material waiting to be transported; } \\
\text { - The service elevator is used by different support } \\
\text { areas, causing waits; } \\
\text { - There is no standard route of transportation to the } \\
\text { units. }\end{array}$ & $\begin{array}{l}\text { - Rhythm of expedition } \\
\text { unbalanced with the } \\
\text { rhythm of preparation } \\
\text { of materials in the } \\
\text { stock, resulting in } \\
\text { a large amount of } \\
\text { material waiting to be } \\
\text { transported. }\end{array}$ & $\begin{array}{l}\text { - There is no team mobilized at predetermined times } \\
\text { to supply the units; } \\
\text { - Absence of standardized sequence in the transport } \\
\text { of materials, being at the discretion of the team } \\
\text { which unit will be supplied first; } \\
\text { - Unbalanced workload; } \\
\text { - There is no standardized routine for the return of } \\
\text { trolleys and boxes. }\end{array}$ \\
\hline
\end{tabular}

\section{Discussion}

\subsection{The 3 R's improvements}

Opportunities for improvement were identified from the analysis of the 3 R's (item 4.4) and were presented to the Logistics Supply Unit team of the hospital. Among the improvement opportunities identified, the following stand out: the creation of a standard route of transportation to the units, the establishment of a transportation rhythm for the serums and the elaboration of a standardized routine for the return of trolleys and boxes.

Specifically, concerning the first R, Route, a practical contribution and an opportunity for improvement is the planning of routes and frequent deliveries to the units (internal pharmacies, emergency, and surgical center) in small lots instead of waiting to accumulate materials for delivery. In this way, it is possible to reduce inventories and reaction time along the value stream. A similar study was carried out by Aguilar-Escobar \& Garrido-Vega (2013), where lean logistics was implemented with the support of a management plan, reaching gains in route times, reduction of the inventory, decrease in lead times and improvement of service quality. Also, there have been other important improvements: enhancement of employee satisfaction and increase of staff productivity, both dedicated to health and logistics.

As for the second R, Rhythm, the key opportunity for improvement is to plan delivery frequencies by applying two fundamental concepts: increasing delivery frequency and synchronizing the flow of delivery. In this way, it is possible to reduce the batch size by increasing the delivery frequency. As a result, the supplier process and all supporting resources will be focused on ensuring that there is a continuous flow of supply to the customer process. Rachmania \& Basri (2013) developed a forecasting model for a hospital and also had good results in the efficiency of patient care and the reduction of stocks. However, the model did not take into account aspects of the synchronization of the delivery flow, for example, route and supply routine.

Regarding the third R, Routine, according to Ghinato (2018), the standardization of routines of operations is a fundamental aspect, creating sequences of activities of manipulation, separation, and transport, executed cyclically, to guarantee the flow by the "routes", in the "rhythm" defined/required. Concerning the case study presented, standardized movement routines could be done by a dedicated employee, stopping at defined points, at known and standardized times, to deliver the serum to the units and collect green boxes. Another practical contribution concerning routine is the organization of serums at the storage site. The application of a standardized storage routine (with visual management and clear demarcation), guaranteeing that materials are stored right at the first time, is of extreme importance. Besides, the organization of this space is fundamental for the separation, selection and conference of materials to be transported, which currently suffers from the lack of adequate space.

Thus, based on the model developed and the 3 R's we could identify a great number of improvement opportunities to the internal logistics of the hospital studied. According to Borges et al. (2019), the introduction 
of a Lean material handling system within healthcare institutions with the materials arriving at the right time and quantity to the patient increases activities and actions that add value to the end customer, generating a series of process improvements, the reduction in direct costs of supply logistics and improved workload balancing of routes. Through the use of the 3 R's approach, further actions may contribute to improving hospital logistics.

\subsection{Theoretical and practical contributions}

The model proposed in this article brings a systemic analysis of internal logistics. The approach proposed here considers not only a demand analysis, or an isolated route analysis, but a new management vision, based on the flow analysis. This is the main contribution brought by the checklist model, and in addition to providing a practical contribution to healthcare organizations, the model also brings theoretical contributions within the scope of lean logistics.

On the theoretical side, the model proposed in this article leverages previous findings on lean and logistics improvement in hospital (i.e. Volland et al., 2017; Regattieri et al., 2018; Feibert et al., 2019). Our model, however, aims at proposing a structured, process-oriented model to improve the logistics system. Previous studies addressed this scope by proposing specific tools and actions for application. Regattieri et al.(2018) proposed a two-phase model focused on an initial analysis, basic material management models and training of employees with logistics concepts, and then applying more advanced technologies such as RFID and dual-bins methods. Feibert et al. (2019) identified seventeen decision criteria for evaluating improvements in the pharmaceutical distribution process (e.g. traceability, security of supply, information management, environmental conditions among others) addressing both efficiency and effectiveness aspects of performance. These criteria proposed can be used for assessing the logistical process on hospitals and increasing the reliability of the value streams in hospitals.

However, such models usually lack a defined framework of improvement actions, which should be structured enough to serve as a guideline, but flexible enough to cope with the specificities of hospital logistics flow, such as the lack of logistic background of employees, organizational barriers or specific healthcare problem settings (Volland et al., 2017). Thus, replication can be hindered or of difficult adaptation in so strictly structured models. The 3 R's approach aims at providing both a defined structure through the use of route, rhythm, and routine as guiding principles and flexibility through suggesting tools that can aid in search for improvements of route, rhythm, and routine such as Gemba walks, meetings, VSM. Nevertheless, these tools can be adapted to suit different contexts in future research or practical contexts, without losing the central focus on value and waste reduction that permeates the 3 R's approach.

On the practical side, our approach provides an empirical analysis of logistical flows that encompass various activities such as storage, transportation, stock control, handling, and material management. These flows are not only present in the industrial sector, but they supply any organizational chain, whether industrial, social, or health, with material, information, and financial resources. The literature reviewed in this article analyzes several articles on flow management, whether logistical or operational. In general, this flow management is conducted by professionals through trial and error, which leads to a waste of time, movements, and unnecessary costs. This article, addressing the 3 R's aims to simplify this application in terms of minimizing this waste through a checklist to guide the application of flow improvements based on three essential pillars i.e. mapping, evaluating, and prioritizing system improvements. Thus, professionals can address logistical and flow problems using this approach which provides guidelines of the tools that can be used for the problems identified in route, rhythm, and routine aspects of hospitals.

\section{Conclusion}

Currently, the main issues related to performance and operating costs in hospitals have roots in logistics and its planning (Volland et al., 2017). Aiming to propose solutions and improvements in such a complex environment, this study sought to develop a model to analyze the logistics flow, considering three macro elements of strong impact in hospitals' operations. The model aims at supporting the identification of problems and solutions with the participation of several stakeholders in iterative steps. Therefore, we developed the model to analyze the logistics flow, which includes 3 R's (Route, Rhythm and Routine).

The tool is based on concepts of the lean philosophy, since it provides means for improvements in hospital organizations in a sustainable and relevant way (Brandao de Souza, 2009), however, it is noteworthy the significant challenge imposed in adapting lean concepts and tools to flow managements involving materials, information, employees and patients in hospitals units, such as the hospital's Logistics Supply Unit studied. We sought to 
approach this challenge using the tools of Value Stream Mapping, time analysis (takt time and cycle time), route analysis, and analysis of the supplying logistics in the development of the framework. The problem was addressed through a case study which allowed the framework refinement and validation.

The results obtained through the case studied showed that an application of the model enables an improved identification of the logistical problems, structured planning for the solution of problems related to time and waste reduction. The proposed model focuses on hospitals and the search for improvements in logistical activities of medications through structured processes. Therefore, managers and other stakeholders can use the model proposed, its principles and steps to reach improvements in the hospital environment seeking greater processes' efficiency, identification, and reduction of costs and waste, which are important factors for hospital management, given that healthcare costs are increasing (Brandao de Souza, 2009). In this sense, the framework should be applied in a structured and interactive manner, with the participation of the stakeholders involved. Still, due to the hospital's complexity, modifications and adaptations may be necessary and are welcome if executed as a complement to the concepts and activities developed in the presented model and if the interdependent aspects of healthcare are considered.

In this sense, Lean Logistics in healthcare settings can significantly contribute to hospitals (Waring \& Bishop, 2010). Still, future studies addressing the aspects of adaptations to other flows and the consideration of new approaches to Lean Logistics oriented toward patient flow are necessary in order to reach significant improvements in hospital settings (Poksinska et al., 2017).

Despite the efforts applied in this research, limitations are present in every scientific study and in this article, this is not different. The study's limitations are the fact that the model's resulting improvement proposals were not implemented, however, such limitation is due to hospital's inherent internal bureaucracies which could not allow the application because of time limitations. To reduce such gap the model proposed was validated by stakeholders, employees and experts to corroborate the feasibility, usefulness and expected results from the model application.

Future research should seek to apply the model in (i) different hospital's sectors, such as patient flow or high complexity medications, or even (ii) identify and define improvements prioritization opportunities through methods such as Analytic Hierarchy Process (AHP).

\section{References}

Aguilar-Escobar, V. G., \& Garrido-Vega, P. (2013). Lean logistics management in healthcare: a case study. Revista de Calidad Asistencial, 28(1), 42-49. http://dx.doi.org/10.1016/j.cali.2012.07.001. PMid:22980756.

Aherne, J., \& Whelton, J. (Eds.) (2010). Applying lean in healthcare: a collection of international case studies. Boca Raton: CRC Press. http://dx.doi.org/10.1201/EBK1439827390.

Alves, J. A., \& Santos, A. P. (2013). Logística lean para redução dos efeitos da variação da demanda no abastecimento de linhas de produção. Journal Perspectivas Contemporâneas, 8(1), 53-66.

Borges, G. A., Tortorella, G., Rossini, M., \& Portioli-Staudacher, A. (2019). Lean implementation in healthcare supply chain: a scoping review. Journal of Health Organization and Management, 33(3), 304-322. http://dx.doi.org/10.1108/JHOM-06-2018-0176. PMid:31122116.

Brandao de Souza, L. (2009). Trends and approaches in lean healthcare. Leadership in Health Services, 22(2), 121-139. http://dx.doi. org/10.1108/17511870910953788.

Bushell, S., \& Shelest, B. (2002). Discovering lean thinking at progressive healthcare. Journal for Quality and Participation, $25(2), 20$.

Costa, L. B. M., Godinho Filho, M. G., Rentes, A. F., Bertani, T. M., \& Mardegan, R. (2017). Lean healthcare in developing countries: evidence from Brazilian hospitals. The International Journal of Health Planning and Management, 32(1), e99-e120. http://dx.doi.org/10.1002/ hpm.2331. PMid:26681656.

Feibert, D. C., Andersen, B., \& Jacobsen, P. (2019). Benchmarking healthcare logistics processes-a comparative case study of Danish and US hospitals. Total Quality Management \& Business Excellence, 30(1-2), 108-134. http://dx.doi.org/10.1080/14783363.2017.1299570.

Gao, T., \& Gurd, B. (2019). Organizational issues for the lean success in China: exploring a change strategy for lean success. BMC Health Services Research, 19(66), 1-11. http://dx.doi.org/10.1186/s12913-019-3907-6. PMid:30678663.

Gayer, B., Marcon, E., Bueno, W. P., Wachs, P., \& Saurin, T. A. (2018). Uma visão Lean sobre a gestão de fluxos hospitalares. In Proceedings of VIIl Congresso de Sistemas Lean. Florianópolis: UFSC.

Gayer, B., Wachs, P., Marcon, E., Bueno, W. P., \& Saurin, T. A. (2019). Análise de fluxo em uma unidade de logística hospitalar sob a ótica do Functional Resonance Analysis Method. In Proceedings of XXXIX Encontro Nacional de Engenharia de Produção. Rio de Janeiro: ABEPRO. http://dx.doi.org/10.14488/ENEGEP2019_TN_STO_290_1634_38567.

Ghinato, P. (2016). Tópicos Especiais em Engenharia de Produção - Sistemas Lean. Porto Alegre, RS: UFRGS. Apostila da Disciplina de Tópicos Especiais, Programa de Pós-Graduação em Engenharia de Produção, Escola de Engenharia, UFRGS.

Ghinato, P. (2018). Gestão de fluxo: a essência da gestão de operações Lean. In VIIl Congresso de Sistemas Lean - Em Busca da Excelência do Fluxo de Valor. Florianópolis: UFSC.

Goodridge, D., Westhorp, G., Rotter, T., Dobson, R., \& Bath, B. (2015). Lean and leadership practices : development of an initial realist program theory. BMC Health Services Research, 15(1), 1-15. http://dx.doi.org/10.1186/s12913-015-1030-x. PMid:26345184.

Graban, M. (2011). Lean hospitals: improving quality, patient safety, and employee satisfaction. Boca Raton: CRC Press. 
Hall, R., Belson, D., Murali, P., \& Dessouky, M. (2013). Modeling patient flows through the health care system. In R. Hall (Ed.), Patient flow (pp. 3-42). Boston: Springer. http://dx.doi.org/10.1007/978-1-4614-9512-3_1.

Harris, R., Harris, C., \& Wilson, E. (2003). Making materials flow. Boston: Lean Enterprise Institute.

Heinbuch, S. E. (1995). A case of successful technology transfer to health care: total quality materials management and just-in-time. Journal of Management in Medicine, 9(2), 48-56. http://dx.doi.org/10.1108/02689239510086524. PMid:10166205.

Holmström, J., Ketokivi, M., \& Hameri, A. P. (2009). Bridging practice and theory: a design science approach. Decision Sciences, 40(1), 65-87. http://dx.doi.org/10.1111/j.1540-5915.2008.00221.x.

Hopp, W. J., \& Spearman, M. L. (2011). Factory physics: foundations of manufacturing management (3rd ed., 720 p.). Nova York: McGraw Hill Higher Education.

Jimmerson, C., Weber, D., \& Sobek 2nd, D. K. (2005). Reducing waste and errors: piloting lean principles at Intermountain Healthcare. Joint Commission Journal on Quality and Patient Safety, 31(5), 249-257. http://dx.doi.org/10.1016/S1553-7250(05)31032-4. PMid:15960015.

Kc, D. S., \& Terwiesch, C. (2017). Benefits of surgical smoothing and spare capacity: an econometric analysis of patient flow. Production and Operations Management, 26(9), 1663-1684. http://dx.doi.org/10.1111/poms.12714.

Khlie, K., Serrou, D., \& Abouabdellah, A. (2016, October 19-20). The impact of Lean-logistics and the information system on the information flow management within the healthcare supply chain. In Proceedings of the 11th International Conference on Intelligent Systems: Theories and Applications (SITA) (pp. 1-5). USA: IEEE. http://dx.doi.org/10.1109/SITA.2016.7772315.

Kriegel, J., Jehle, F., Dieck, M., \& Mallory, P. (2013). Advanced services in hospital logistics in the German health service sector. Logistics Research, 6(2-3), 47-56. http://dx.doi.org/10.1007/s12159-013-0100-x.

Liker, J. K., \& Karlin, J. N. (2018). Just-in-Time and trucking logistics: the lean learning enterprise. In C. White 111 (Ed.), Trucking in the age of information (pp. 229-262). London: Routledge.

Maijala, R., Eloranta, S., Reunanen, T., \& Ikonen, T. S. (2018). Successful implementation of lean as a managerial principle in health care: a conceptual analysis from systematic literature review. International Journal of Technology Assessment in Health Care, 34(2), $134-146$. http://dx.doi.org/10.1017/S0266462318000193. PMid:29642955.

March, S. T., \& Smith, G. F. (1995). Design and natural science research on information technology. Decision Support Systems, 15(4), 251266. http://dx.doi.org/10.1016/0167-9236(94)00041-2.

Marchwinski, C., \& Shook, J. (2003). Lean lexicon: a graphical glossary for lean thinkers. Boston: Lean Enterprise Institute.

Mazzocato, P., Savage, C., Brommels, M., Aronsson, H., \& Thor, J. (2010). Lean thinking in healthcare: a realist review of the literature. Quality \& Safety in Health Care, 19(5), 376-382. http://dx.doi.org/10.1136/qshc.2009.037986. PMid:20724397.

Monden, Y. (1993). The Toyota management system: linking the seven key functional areas. New York: Productivity Press.

Myerson, P. (2012). Lean supply chain and logistics management. New York: McGraw-Hill.

Ohno, T. (1988). Toyota production system: beyond large-scale production. Boca Raton: CRC Press.

Papalexi, M., Bamford, D., \& Dehe, B. (2016). A case study of kanban implementation within the pharmaceutical supply chain. International Journal of Logistics Research and Applications, 19(4), 239-255. http://dx.doi.org/10.1080/13675567.2015.1075478.

Poksinska, B. B., Fialkowska-Filipek, M., \& Engström, J. (2017). Does Lean healthcare improve patient satisfaction? A mixed-method investigation into primary care. BMJ Quality \& Safety, 26(2), 95-103. http://dx.doi.org/10.1136/bmjqs-2015-004290. PMid:26864659.

Rachmania, 1. N., \& Basri, M. H. (2013). Pharmaceutical inventory management issues in hospital supply chains. Management, 3(1), 1-5.

Regattieri, A., Bartolini, A., Cima, M., Fanti, M. G., \& Lauritano, D. (2018). An innovative procedure for introducing the lean concept into the internal drug supply chain of a hospital. The TQM Journal, 30(6), 717-731. http://dx.doi.org/10.1108/TQM-03-2018-0039.

Rico, R. A., \& Jagwani, J. M. (2013). Application of lean methods to compounding services in hospital pharmacy. European Journal of Hospital Pharmacy. Science and Practice, 20(3), 168-173. http://dx.doi.org/10.1136/ejhpharm-2012-000221.

Rivard-Royer, H., Landry, S., \& Beaulieu, M. (2002). Hybrid stockless: A case study: Lessons for health-care supply chain integration. International Journal of Operations \& Production Management, 22(4), 412-424. http://dx.doi.org/10.1108/01443570210420412.

Rother, M., \& Harris, R. (2001). Creating continuous flow: an action guide for managers, engineers and production associates. Boston: Lean Enterprise Institute.

Rother, M., \& Shook, J. (2003). Learning to see: value stream mapping to add value and eliminate muda. Boston: Lean Enterprise Institute.

Rummler, G. A., \& Brache, A. P. (2012). Improving performance: How to manage the white space on the organization chart. Hoboken: John Wiley and Sons.

Smalley, A. (2004). Creating level pull: a lean production-system improvement guide for production-control, operations, and engineering professionals. Boston: Lean Enterprise Institute.

Sutherland, J. L., \& Bennett, B. (2007). The seven deadly wastes of logistics: applying Toyota Production System principles to create logistics value (CVCR White paper \#0701, pp. 40-50). Bethlehem: Lehigh University.

Vaishnavi, V. K., \& Kuechler, W. (2007). Introduction to design science research in information and communication technology. In V. K. Vaishnavi, V. K. Vaishnavi \& W. Kuechler. Design science research methods and patterns: innovating information and communication technology. United Kingdom: Taylor \& Francis Group.

Van Aken, J. E. (2004). Management research on the basis of the design paradigm: the quest for field-tested and grounded technological rules. Journal of Management Studies, 41(2), 219-361. https://doi.org/10.1111/joms.2004.41.issue-2.

Volland, J., Fügener, A., Schoenfelder, J., \& Brunner, J. 0. (2017). Material logistics in hospitals: a literature review. Omega, 69, 82-101. http://dx.doi.org/10.1016/j.omega.2016.08.004.

Waring, J. J., \& Bishop, S. (2010). Lean healthcare: rhetoric, ritual and resistance. Social Science \& Medicine, 71(7), 1332-1340. http:// dx.doi.org/10.1016/j.socscimed.2010.06.028. PMid:20702013.

Wilson, L. (2010). How to implement lean manufacturing (pp. 45-197). New York: McGraw-Hill.

Xie, Y., \& Peng, Q. (2012). Integration of value stream mapping and agent-based modeling for OR improvement. Business Process Management Journal, 18(4), 585-599. http://dx.doi.org/10.1108/14637151211253747.

Zylstra, K. D. (2012). Lean distribution: applying lean manufacturing to distribution, logistics, and supply chain. Hoboken: John Wiley \& Sons. http://dx.doi.org/10.1002/9781119201427. 